\title{
Social Closure in Lesotho: Forms and Manifestations
}

\author{
Tankie Khalanyane
}

Senior Publications Officer, Institute of Southern African Studies National University of Lesotho, P O Roma 180, Lesotho

\begin{abstract}
Using the Social Closure Theory by Parkin (1979), the article art iculates socialc losure tendencies in Lesotho. It concentrates on the two main tenets of the theory which are exclusion and usurpation. The article looks at these forms in the realm of education, politics, religion, ethnicity and other social formations such as labour movements in Lesotho. It attempts to show how these forms of social closure manifest themselves in these public spheres of life in Lesotho. It also argues that social closure does not only happen in institutions but even amongst individual group members themselves. In addition, social closure is not treated as a static process but a dynamic process which also has elements of power relations and ideology as well.
\end{abstract}

Keywords Social Closure, Exclusion, Dual Closure, Usurpation, Credentialis m, Professionalization

\section{Introduction}

It is however expedient and benefiting to start by attempting to give a crude definit ion of social closure so that we could start and operate on a common ground. Social closure is a process in which a group of eligibles bars other groups access to social resources and opportunities. Race, status, religion, language, gender, social origin are some of the social or physical attributes which could be used as justification to deny other groups in the society access to the resources and other economic opportunities. The prime motive of groups which practice social closure in its all forms is to maximize their monopolization of the resources and economic opportunities. However, the approach that would be adopted in this article would not be economically deterministic, because it shall be argued that the groups on which social closure is directed do show some form of resistance against the practice. In addition, human behaviour is not determined by economy only; a host of social factors are also involved. Moreover, human beings can manipulate economy not that economy can manipulate or enslave them. Also it is has to be born in mind that; though, the article will look at social closure as practiced by collectivities, the article does not presuppose that individuals are immune from practicing social closure upon other individuals.

\section{Forms of Social Closure and their Manifestation}

The most common and pervasive form of social closure is

\footnotetext{
* Corresponding author:

T.Khalanyane@nul.ls (Tankie Khalanyane)

Published online at http://journal.sapub.org/edu

Copyright (C 2012 Scientific \& Academic Publishing. All Rights Reserved
}

exclusion. Exclusion is a form of social closure by which a group of few individuals bar other groups access to resources and economic opportunities. Exclusion can be done through credentialis m (including professionalization), membership, religion and ethnicity.

\subsection{Cre den tialism}

In education the most common way of excluding some other groups is through the use of academic credentials or qualifications or in short credentialis $\mathrm{m}$. Credentialism is a process of social selection in which class advantage and social status are linked to the possession of academic qualifications[1]. Credentialis $m$ expresses the ideology that qualifications reflect either the expertise or attributes necessary for social ascent or the occupancy of élite roles. It is said that an unintended consequence of credentialism, especially in developing societies, is credential inflation or so-called diploma disease. This practice is sanctioned by many states world wide to such an extent that groups which are excluded from the resources and other economic opportunities take it as 'given'. The group which has credentials excludes other groups from employment opportunities by requiring credentials from the groups which aspire to have a share in the resources of the state. Groups with educational certificates normally exclude the groups without certificates from certain benefits like insurance, old age pensions and other essential benefits. By so doing the certificated groups are monopolizing economic opportunities for themselves at the expense of other groups. When people aspire to further their studies under the pretext of self improvement, they are covertly trying to maximize their chances of being included in the group of the eligibles so that they could have a bigger share in the national resources.

Defining educational credentialing some theorists say it refers to the use of the familiar symbols or markers of 
knowledge (e.g., grade levels, dip lo mas) conferred by formal educational institutions to monitor entry into occupations. They further argue that credentialing can restrict the labor supply in two ways, depending on the perspective one takes on the nature of educational credentials. One view posits that educational credentials certify the acquisition of real skills, and, as a result, any restrictions on opportunities to attain these credentials-whether through the influence of accrediting boards, the scarcity of native ability, or the "considerable expenses and long period of gestation" training entails - will shrink the pool of candidates who have the skills necessary to perform an occupation's tasks.

One other theorist adds that; employers and consumers, in turn, support credentialis $m$ as "a necessary device for narrowing the range of choice"[6] among candidates in a world in which alternative ways of judging expertise (e.g., trial employment, word-of-mouth testimonials) are simply too cumbersome or costly. An alternative perspective by some other authors on the subject, argues that educational credentials are only loosely, if at all, related to the knowledge a person needs to be competent or productive in an occupation. Instead, these credentials serve as a largely arbitrary "cultural currency" that buys membership into a particular club[7, 8, 9, $10 \& 11]$. In th is view, credentialing restricts the labor supply because employers, occupational gatekeepers, and consumers value the cultural currency and believe that the credential certifies a unique capacity to perform a set of skills. So me authors contend that ; although a given occupation has little control over the cultural value attached to educational credentials, there is no shortage of examples of efforts by emergent or existing occupations to introduce specialized curricula into postsecondary educational institutions, develop specialized schools, encourage the state to support credentialism as a legitimate basis for exclusion, require special examinations or educational credentials as a precondition for entry into the occupation, or where occupational representatives do not directly make hiring decisions, define job requirements and prerequisites in ways that encourage employers to support credentialis $\mathrm{m}[12 \& 6]$.

One other tendency is for the higher educated or the elite to entrench themselves in positions of influence and opportunity, they tend to marry among themselves not across groups. This tendency to marry someone within the same educational level is called 'educational homogamy'[13]. It is one of the most important forms of social closure in modern societies because it can determine one's occupational placement and social success.

Closely linked with credentialism is professionalization. Professionalization is an exclusionary device used by certificated groups to bar other groups from sharing the resources allocated to them or their profession. The rationale behind professionalization is to limit and control the supply of entrants to an occupation in order to safeguard or enhance its market value. Both credentialism and professionalization tend to stress importance of having certificates rather than one's ability to perform a particular duty. Credentials are merely used to justify and legitimize exclusion process. They are therefore a form of discrimination which seems to be sanctioned by most progressive states and institutions.

\subsection{Membership}

At the political level groups are excluded on the grounds of a peculiar form of credentialis m commonly known as 'membership'. If a person or a group of people does not hold the membership card(s) of a particular party or group s/he may be denied access to certain resources and economic opportunities which are normally given to the card holders of that particular party. It is a matter of whether one is a me mber of Lesotho Congress for Democracy[LCD] or not or a Basutoland Congress Party[BCP] member or not in order to be eligible to certain social and economic benefits. Two decades ago if a person seeking employment or any kind of service was not a bearer of the Basotho National Party[BNP] card, such a person was 'normally' denied employment or that essential service. Students who wanted to study at The National University of Lesotho[NUL] were also denied loan bursaries on the basis of political affliction. We therefore had the eligibles and the ineligibles within the society. Drifting slightly away from home one could point at the exclusion in the political arena on the basis of race as it happened in the then apartheid South Africa, when Africans were excluded from most social and economic opportunities purely on racial basis. The small group of the eligibles, that is, Europeans enjoyed profound and exclusive economic and social benefits at the expense of the ineligibles, that is, Africans.

At the classroom level some students may be denied access to tuition on the bas is of having not paid the fees. The group of few eligibles is 'normally' offered tuition while those excluded the ineligibles, are barred access into the classroom. In admitting students into the schools some students may be denied admission into some schools on the basis of their places of orig in. Here it is a question of whether the student is domicile in Roma or not, Ha Abia or not and so on. Among the teaching staff some members are usually excluded from others on the basis of gender, that is, a male teacher and a female teacher. Qualifications or what earlier was labelled as credentialism - a qualified and unqualified teacher or certificate holders, dip lo ma holders and degree holders.

Religion is another aspect in which social closure manifests itself at institution level, in that, some teachers excluded others from some economic and social opportunities on its basis. Some teachers are excluded from some positions in the school on the on the basis that they are non-Catholics, non-Anglicans or non-Evangelists. The latest form of exclusion in most schools among teachers is on the grounds of organizational affiliation such as Lesotho Teachers' Trade Union[LTTU] member or non-member and Lesotho Association of Teachers[LAT] member and non-member. The eligib les in these groups bar the ineligibles access to some social and economic opportunities. Religious orders within the same broader religious body do exclude 
one another from certain economic and social benefits. For example, the Oblates excluded SCP, Dominicans and other religious group orders from the economic and social opportunities. The Anglicans excluded Catholics and other religious groups from certain social and economic opportunities and vice versa, yet they claim to be spreading the Word of God. Also among the Oblates some other members of the order are the ineligibles while others are the eligibles. The same thing applies to other religious orders. However, all these examples cited do not presuppose that among all the professions teaching is the most open profession where people without appropriate credentials are allowed to practice, while in other professions like medicine, the legal field and others the barriers are heavy.

One interesting example on how social closure manifests itself at institutional level is that of Lesotho University Teachers and Researchers Union[LUTA RU] of the National University of Lesotho. LUTARU wanted its members to be paid differently from the non members of the union. The exclusionary strategy they were using was credentialism, that is, academic and non-academic staff, lecturers and non-lecturers, researchers. So it wanted all the non-academic staff to be excluded from the economic and social opportunities which they bargained for and negotiated for its members.

\subsection{The Workplace}

In the workp lace or labour market social closure in a form of exclusion can be noticed in the following ways. First, in order to exclude and bar entry into the labour market of new graduands, the eligibles would require the applicants to have certain work experiences. The applicants may be barred through age restrictions. Other attributes commonly referred to are the applicants' state of health, track record and language. Exclusion on the basis of language is pervasive in most job advertisements and what is interesting about exclusion on the bas is of language is that emphasis is usually on the fluency in foreign languages as against local languages even when jobs require 'suitable localcandidates'.

Second, exclusion at the workplace can be noticed through ethnicity and place of origin. That is, if the Managing Director is ethnically a Motaung he/she will try to give the position to a pers on of his/her ethnic group. The family name is also an important exclusionary strategy in Lesotho. If a person is not a Molapo, Letsie, Mohale or from the royalty, his or her chances of getting an essential service, employment or even being given a hearing are 'normally' near zero on any scale. In this case, what is important is, who one is, not the credentials one has so that one could be part of us [eligibles] or part of them[ineligibles]. Many children have failed to marry girls or boys of their choice because of exclusion along ethnic lines. We have often heard parents say; 'You can not marry a Mokhatla nor a Motaung my son/daughter, you have to marry a Mokoena or Motlokoa. Though, ethnicity in Lesotho is overtly not that pervasive, it is covertly strong and healthily used as an exclusionary strategy. Origin, which is where one was born is another important exclusionary strategy used at the workplace. If the person having capacity to recruit and employ people into particular jobs, happens to be from Mafeteng, that particular person will recruit and employ Makaota. Lijabatho, Liphamola or Likila will be excluded from economic opportunities. This reminds one of an incident at one teachers' Training College, where more than $60 \%$ of staff members were Liphamola simply because the director of the College was a Phamola.

Other general exclusionary strategies are based on what one could call labels. All teachers in Lesotho are excluded from the resources, and economic and social opportunities on the basis that they are not 'civil servants' or 'government employees', yet their monthly salary comes from public coffers. The services they offer are social. Teachers in this case are ineligibles or outsiders merely advancing economic monopoly of the few eligibles, which in this case are the 'civil servants'.

\section{Usurpation and Usurpationary Actions}

The ineligibles are not a helpless group in the society; instead they are proactive agents which strive to usurp what is denied them by the eligibles. This then brings us to the second form of social closure, which is usurpation. Usurpationary actions are aimed at biting into the resources and benefits enjoyed by the group of eligibles. The usurpationary actions of the ineligibles are usually not sanctioned by the state because they are regarded as illegal by the status quo, while the exclusionary activities of the elig ibles are usually sanctioned and supported by the state. The group of the eligibles, since its usurpationary activities are not sanctioned by the state, relies heavily on the public mobilization of members and supporters, as in the use of strikes, demonstrations, sit-ins, marches, stay-aways and the like.

As pointed out earlier, the usurpationary activities of the ineligibles are embarked upon by the group in order to get a fair share from the resources, social and economic opportunities. The ineligibles in attempting to get a fair share of the resources usually pledge solidarity from other similar groups. In other words, usurpation can also mean solidarism. However, when the eligibles try to usurp a slice from the national cake, they are dealt with heavy handedly by the state which seems in most cases to support and protect the interests and aspirations of the eligibles. Live examples in Lesotho are that in 1995, when teachers tried to usurp a share from the resources through demonstrations, marches, sit-ins and strikes, the state used its repressive state apparatus (RSA) or police to apprehend the leaders, teargassed the teachers and torched them up, because their actions were regarded illegal by the state. In 1996 construction workers at 'Muela in the Butha-Buthe district embarked on a sit-in as a way of pressing the eligibles to give them a fair share of the 
resources. They were instead mowed down by live bullets by the RSA, and hundreds of wo rkers lost their lives while so me were maimed. These two incidents are examples of usurpation at political level.

At school or institutional level the example is of students strike in schools, colleges and university, where students often complain about food, accommodation and fees to mention but a few things. Students are usually dealt with heavy handedly by the authorities in that some students get suspended from the school, while others are expelled altogether. At times the RSA is usually called into the school campus where it teargases students and apprehends and takes them to the police cells for lengthy interrogations. Recently in November 2009 a student was shot dead by police during students riots.

\section{Conclusions}

The article has attempted the two major forms of social closure and has illustrated by examp les across the spheres of life how the two forms manifest thems elves in the context of Lesotho.

\section{REFERENCES}

[1] Marshall, G. (ed) (1998). "Credetialism”. In A Dictionary of Sociology. Oxford University Press: USA.

[2] Weber, M. (1922/1978) Economy and Society: An Outline of Interpretive Sociology. Edited by Roth, G \& Wittich, C. Berkely and Los Angels: University of California.
[3] Parkin, F. (1979). Marxism and Class Theory: A Bourgeois Critique. Columbia University Press: USA.

[4] Sorensen, A. (2000) "Symposium on Class Analysis: Toward a Sounder Basis for Class Analysis." American Journal of Sociology, Volume 105, Number 6: 1523-58.

[5] Wright, E. O. (1979) Class Structure and Income Determination. New York: Academic Press.

[6] Freidson, E. (1994) Professionalism Reborn: Theory, Prophecy, and Policy.Cambridge: Polity Press

[7] Collins, R. (1971) "Functional and Conflict Theories of Educational Stratification". American Sociological Review 36(6):1002-18

[8] Collins, R. (1979) The Credential Society: An Historical Sociology of Education and Stratification. New York: Academic Press.

[9] Berg, I. (1970) Education and Jobs: The Great Robbery. New York: Praeger.

[10] Jencks, C. (1979) Who Gets Ahead? The Determinants of Economic Success in America. New York: Basic Books.

[11] Bourdieu, P. (1984) Distinction: A Social Critique on the Judgement Taste. Cambridge, Massachussetts: Harvard University Press.

[12] Abbott, A. (1988) The System of Professions: An Essay on Division of Expert Labor. Chicago: University of Chicago Press.

[13] Smits, J. (2003). "Social Closure among the Higher Educated: Trends in Educational Homogamy in 55 Countries". Social Science Research, Volume 32, Issue 2, June 2003, p.251-277. 